\title{
War, Death and What Remains in the Poetry of Joy Harjo
}

\author{
By Sally Michael Hanna*
}

\begin{abstract}
In order to understand American Indian literature, one has to skillfully situate it within the context of atrocities done unto American Indians. Such atrocities include killings, forced eviction, trauma, rape and assimilation. Historical and cultural contexts are imperative for readers to help piece together a mosaic of suffering that American Indians beautifully transform into art represented in stories, poems, music and visual art that stand as instances of witness. Angelique Nixon elaborates on the nature of the required context as "both ritual and historical, contemporary and ancient" (3). American Indians have drawn extensively on myth and legend which they have employed to ensure their survival and their belonging to nature and their ownership of the story of their being. Creating a combination of oral and written literary conventions enriches the poetic texture and ensures outreach and readership that is ready to be taken by surprise. Singing through their degradation and elimination is a choice that most American Indian writers including Joy Harjo have opted for in their careers as writers.
\end{abstract}

*Associate Professor, 6 October University, Egypt. 
Wars, Hernandez Avila argues is an integral part of Indian life over the past five centuries with special reference to women warriors (IX). I would like to dedicate this scholarly endeavor to wars, associations of death and dismemberment and their attendant consequences in the poetry of Joy Harjo. I propose to locate such representations as they spell destruction and loss for the victor and the vanquished alike. The wars depicted in her work take place on political levels as well as on the level of the personal represented in social conflict or in conflict with the self. Harjo's poetic oeuvre focuses on both the physicality and the spirituality of loss and growth in loss in an act of witness. I would like to contend, however, that in dealing with war, Harjo echoes not only destruction but discovery about the self and the things that are no more. Her attempts to problematize death as journey and to reinvent it, will be considered along with the motifs of dispossession of voice, dismemberment and imprisonment. In her attempt to explore the nature of enmity, she offers myriad depictions of the enemy as other and as self, as a repercussion or as an emotion that needs to be conquered. Moreover, Harjo's poetry seems to work on the dichotomy between war and death on the one hand and grace and love on the other (Randall 1990:18). Presenting grace and love as what lie beyond war and death, is explored through a depiction of poems from In Mad Love and War, A Map to the Next World and The Woman Who Fell From the Sky.

Joy Harjo is a woman of many artistic talents. Poetry to her is not only a raison d'etre but also a 'house for the spirit' that ensures a home coming; a shrine in which humans can learn to be and a force field that always promotes the best in humanity. Hers has always been an attempt to find peace in the world through poetry despite the atrocities around her. In an interview with Marilyn Kallet, Harjo referred to poetry as a 'prayer of continuance' (66) a process in which one has opened oneself up to the creator. Reading Harjo, one has to bear in mind that she is a poet of polarities who orchestrates a concerto of opposites as she labors quite dutifully through repetition as emphasis of the power of language and constant mention of nature as a shrine of being, to dissolve apparent contradictions. Visual, musical and vocal, Harjo's poetry creates a threshing ground for all her readers to be schooled in the art of naming and claiming.

As an American Indian, Harjo voices a culture under siege in almost all her works poetic and musical through attempts to lift off this setting to a world of her creation, one that goes beyond division and despair. Despite the fact that almost all American Indian literary works testify to a chronic reference to misery (Gould1995:798), Harjo recreates through verse an imaginary "world without colonialism" (Fowler 32). Ever since her childhood, Harjo was confronted with the atrocities of the Indian Removal Act and what it induced in terms of the constant feelings of dislocation, physical and spiritual displacement and destruction. Hers is a poetry that always travels representing moments of separation and return. Laura Coltelli argues that Harjo's early volumes confirm to a "cyclical pattern of unity, separation and longing followed by the journey for recovered experience; and the reunion, only temporary, after which there begins again the cyclic quest of a voice looking 
for home" (Spiral 6). It is a recurrent observation that Harjo's poems always lead back into one another creating a non ending chain of representation describing a chronic situation of loss that colors almost all Indian American writing. Later volumes testify to an unmistakable sense of movement from one poem to the other as though representing a pilgrimage that combines wandering and a deep rooted determination to chart a path out of loss. Moving is Harjo's way to explore and learn as she proclaims "I find images or sounds by moving them, and moving with them" (Winder 1169). Harjo's spatial journey is not a journey in the space of dislocation but rather in places of memory that take her back to Oklahoma, the red earth shown in Secrets from the Center of the World, her place of birth and tribal affiliation and proceeds to a desert landscape, rife with life then to Alabama where the Creek tribe lived before the Indian Removal act (Coltelli, Spiral 5). Harjo reconciles herself to both her land as original place, and to the loss of such land. Instead of mourning over loss of land, she recreates it in vivid detail in memory of verse that eventually gives a true poet a voice (Lang 49). A constant sense of journeying colors her work as she tells Coltelli about the forced walk away from her original homeland: "Perhaps that is also why I am always traveling" (Coltelli, Spiral 7).

For Harjo, to commune with nature is "to stand at the center of miracles (Secrets 14). However, her love of nature was chattered with the realization of the ruthless mishandling by a people supposedly her own. Taken away from nature is a cause for bereavement that colors her verse along with the need to reconcile oneself to nature as a metaphor of wholesomeness and regeneration. Nature is represented as the only resource of self completion in a journey of breakage. J. Scott Byrson calls attention that modern alienation according to Harjo emanates from an ignorance of nature's wildness and humans' relationship to that wildness. This ignorance results from an under-developed appreciation of space and leads to an arrogance that makes humans feel and act as if they can control forces obviously beyond their control" (172). Her poetry perceived as an energetic matrix, shaped by meaning and words emphasize the interrelation of all things in the world. Nature and humanity are subsumed in each other in a balancing act of harmony that testifies to their wholesomeness and belonging in what she refers to in Secrets From the Center of the World as the 'non separate' (1). The devilish side of human nature became the locus of her work together with an attempt to bring them back to the selves they have long lost.

In Witness from her volume The Woman who Fell from the Sky, Harjo establishes the motif of continuity of war in the lives of Indian Americans as she summarizes the culture of assault that has assailed her people and rendered futile the need to set roots. Wars seem to rage in the lives of protagonists because as Jenny Goodman argues "memory is not bracketed off in the past; it bears on the present" (1996:49).Greed is named as an initiator for the search of the land of spice and gold. Destruction was imminent and hatred was the only inheritance of difference: 
The Indian wars never end in this country. We could date them as Beginning with contact by Columbus, an Italian hired by the Spanish court to find the land of spice and gold. Of course we fought intertribally and among ourselves, but a religious fervor large enough to nearly destroy a continent was imported across the Atlantic.

We were hated for our difference by our enemies

The civil rights movement awakened many of us to the beauty in our difference. We began to understand how oppression had become our eyes, our ears, our tongues-we rose up together and continued to sing, as we always had, but with more pride, a greater love for ourselves. We were energetic with our remembered love and stood with each other. The tragedies of loss and heartbreak appeared even more terrible at this time.

During this reawakening I remember being in the thick of plans for the new world, in coffee houses, in the pine smell of mountain retreats, on the roads. We are still working on them (41).

The poem establishes a direct reference with the Civil Rights Movement, an uprising that brought to life the urge to belong and to bring an end to racism. The standards that Martin Luther Kind Jr. stood for are the same as those that Harjo attests to. Although oppression is a reality that cannot be contested, pride becomes the inheritance of those who persevere against wrong doing. The poem concludes on a positive note "we are still working on them" as though to stress her insistence in the belief that change is possible and that the human heart is not beyond repair. When one talks about wars in retrospect, one conjures up a narrative fabric that brings history and memory, fear, pain and destruction, and enemies together in an act of naming that aims at possible neutralization of negativity, acknowledgement of pain and fear and transcendence of them. History to Harjo carries with it the burden of acknowledgement of destruction which made it more of a mine field that can only be approached when one is ready for a real confrontation with tribal history which she later attempted to witness and retell. In one of her interviews she refers to the "weight of that knowing, which means the acknowledgment of destruction" (Jaskoski 1990:10). In Returning from the Enemy from her volume A Map to the next World, Harjo states that "it is time to begin. I know it and have dreaded the knot of memory as it unwinds in my gut." Adamant to recall, Harjo refers to her generation as "the door to memory" (Crazy 21) representing an "unwavering condition of witness" (Root 184). The best way to deal with historical loss is to embrace it and to use every story to recreate it (Gibson 2002:106). In telling, Harjo has emerged as a warrior keeping stories of heroism alive. 
She makes the best use of the power of marginal spaces represented in mythology and narratives of trespass to bring back to rhythm the essence of a humanity once lost because of what she calls American "over culture" (Winder, Intro 134) or the culture of buying and selling. Myths take the readers back to a time in which human and nature were united to reaffirm ancient heritage and our connection to it. Employing myths, she also helps create as Andrew Wiget argues "an alternative reality" (600) through a system of symbols that she employs to bring about a visionary world that transcends the real in favor of what is truthful. Myths may also be formulas for transcendence and agents of crossing as Mary Leen argues that myths are "performance that renders the effect of making boundaries disappear" (4). Stories, according to her, resurrect a past that was never totally transcended and that in turn may bring about wars and destruction. Hers is a tendency to historicize through stories in order to purge all the negative energy of loss into a positivity of being and survival. Moreover, myths represent a space of naming (Ruppert 27), in a descriptive instance, of war as history and grace as exorcism of its evils and transcendence of the havoc that it wreaks.

About the importance of language in Native American writing, Dean Rader (2002:147) argues that "native communities have invested in language the ability to control identity and destiny" as it becomes a mover and a shaker of reality. Inspired by indigenous writing, Harjo adopts confrontation in the language of the enemy as the resolution in the face of personal and tribal annihilation. In an act of reversal of fate from vanquished to victor, she speaks directly in a language that symbolizes the destruction of her people as she turns it into a power of creation of a landscape of liberation (Jossa 2007:588). She proclaims that speaking in this language is a refusal to be defined by someone else's standards. Language becomes a site of human empowerment capable of healing, regeneration, creation and the penetration of a spiral of human experience. Language becomes the medium in which fear is neutralized and therefore emerges as a path to healing. Naming pain is in itself the process of releasing oneself from its strangle hold over us.

Representations of the enemy are clearly delineated in many poems from her volume Mad Love and War, a book that Leslie Ullman has described as a text written "in a moment of urgency" (180) representing a warrior attitude in an attempt for victory. We must Call a Meeting from her volume Mad Love and War is a prayer in song that acknowledges both the fragility and determination to name the enemy and to make peace with such an entity. A search is set and a journey started to hunt down a name that was elusive at best. Creativity is the order of the poem represented in a piercing arrow, initially lost but later found a way to the very heart of its own fear. The language in question is one that was long misappropriated by an enemy but is challenged by "an arrow painted with lightening" capable of appropriating the language of the enemy into a language of nature of "lizards and storms." Fusion of nature and humanity is quite unmistakable in this poem that emphasizes the interrelation of all things. 
I am fragile, a piece of pottery smoked from fire

made of dung, the design drawn from nightmares. I am an arrow, painted

with lightning

to seek the way to the name of the enemy,

but the arrow has now created

its own language.

It is a language of lizards and storms, and we have

begun to hold conversations

long into the night (9)

Harjo delineates with vivid colors images of starvation, loss, suffering and grieving as constant realities of the life of the American Indian. She invokes the powers invested in nature and in ancestry to find a voice charting away out of the ashes of destruction.

\section{I forget to eat.}

I don't work. My children are hungry and the animals who live

in the backyard are starving.

I begin to draw maps of stars.

The spirits of old and new ancestors perch on my shoulders.

I make prayers of clear stone

of feathers from birds

who live closest to the gods.

The voice of the stone is born

of a meeting of yellow birds

who circle the ashes of a smoldering volcano.

The feathers sweep the prayers up

and away.

1 , too, try to fly but get caught in the cross fire of signals

and my spirit drops back down to earth (9).

Hunger and starvation in the poem are mentioned both literally and metaphorically but such negativity gives rise to dreams and a will to change the current reality. History represented in her ancestry empowers her to lift up her pain in supplication. A voice as steadfast in resolve as stone is born and it tells the story of harshness that culminated in death of a volcano; an explosion of self that eventually subsided and died in the process of telling. Feathers of birds lift off the incantation as though in a ritual right of passage to God. The extensive reference to nature establishes it as a refuge, an ally and the power of continuity. Confusion reigns over the poem as she proclaims loss and calls for her right to reclaim her home in order for the dying to survive. Although seemingly confrontational the poem assumes a tone of love and inclusion rather than exclusion. The naming here is more the naming of pain caused by the enemy rather than a naming of the enemy himself. 
I am lost; I am looking for you

who can help me walk this thin line between the breathing

and the dead.

You are the curled serpent in the pottery of nightmares.

You are the dreaming animal who paces back and forth in my head.

We must call a meeting.

Give me back my language and build a house

Inside it.

A house of madness.

A house for the dead who are not dead.

And the spiral of the sky above it.

And the sun

and the moon.

And the stars to guide us called promise (9)

A search for the naming of the enemy and a need to seek his help represents Harjo's attempt at making peace with the aggressor other. Peace and grace not war are the answers that Harjo comes up with in the poem.

In Returning from the Enemy from the volume A Map to the Next World, Harjo invokes her heritage and belonging to her tribal family and associates her existence to that of "water," a power of continuity and cleansing as she approaches the heroic act of returning from the enemy. Returning from the Enemy is a right of passage and an act of witness that may be rightly associated, Tanaya Winder argues, to an act of cleansing (340). The poem represents fluidity of time that bends linear time against eternal time in an attempt to make an opening in consciousness with both strategies of time" (Winder 1149) in order to heal the rift of memory.

The wake of history is a dragline behind me. I am linked to my father, my son,

my daughter. We are relatives of deep water.

And the enemy who pressed guns to our heads to force us to Oklahoma still

walks in the mind of the people.

But I hear relatives' voices in the wind as we gather for the reckoning. I carry

fire in my hands to the edge of the water.

And continue to believe we will make it through the bloodstream to the ceremony

for returning from the enemy (69).

In this poem Harjo names the enemy in terms of vivid acts of aggression as she records the details of deportation to Oklahoma. The poem represents a 
rehistoricization of an event that lurks in her mind. The final day of reckoning brings to life all the dead relatives who in turn condemn acts of aggression.

Vertigo is a terrible mode of travel.

It returns you perpetually to the funnel of terror.

I want it to stop and am furious that fear has found me here,

In the sun where people are laughing, doing ordinary things.

I want to be ordinary, I mean, with no worry that my house will be burned

Behind me that my grandchildren will become the enemy.

I have held before me the god of fear. My heart is my house. A whirlwind is blowing it down.

I have bowed my head to those who would disrespect me. My neck appears to be broken in half by shame. I have lost my country.

I have handed my power over to my enemies. My shoulders bear each act of forgetfulness.

I have abandoned my children to the laws of dictators who called themselvespriests, preachers, and the purveyors of law. My feet are scarred from the steps taken in the direction of freedom.

I have forgotten the reason, forgive me. I have forgotten my name in the language I was born to, forgive me (69).

Fear is named as a concomitant to war that feeds off the goodness in the protagonist's life. Fear is characterized as the enemy that poisons her life and the lives of her children as they become the enemy. One notices the interrelatedness between fear as an emotion that grips the heart and fear as an emotion that engenders the enemy. Harjo builds a continuum in which those who fight and those who fight back become the two facets to one coin; evil. However, she believes that anger, if controlled can be transformed into power (Spiral 8). Harjo testifies to the limitation of destruction that human wars incur, although they may silence a people for a while but not forever.

The enemy made a circle of piss to claim us.

He cut everything down to make his cities and factories and burned the forest to plant his fields. The wound so deep

it can be seen far above this blue green planet, far above us.

You cannot destroy a soul though you may destroy a planet.

You cannot destroy a song though you can make a people forgetful.

A soul can appear to be destroyed, and a song can disappear for a few generations

only to reemerge from the heart of a child who turns and becomes a woman (69).

The poem marks the end of silence "as a space of creative possibility" (Winder 1128) in favor of the telling. Harjo closes this sequence with a 
reference to a massacre in El Salvador (Triplopia 389-394) that mimics the atrocities committed unto American Indians ages past. Harjo miraculously reconstructs the scene of rape of a girl who chose to sing through her degradation rather than accept that degradation, and in so doing she rewrites her way out of infamy as she seeks unison with nature, a regenerative power of wholesomeness that reinstates her people. The song in the poem engages as a ritualistic power of reckoning that brings assassins to a judgment far stronger than that of man. The last question in the poem "Can you hear her?" testifies to the continuity of celebrating a hurt that ensures a baptism into a humanity at once loving and forgiving.

There was a massacre in El Salvador. 'The soldiers had gathered all the men and boys in the church at the center of town and killed them, Then the women and the girls were taken to the fields and raped and killed. One particularly beautiful one was assaulted by many soldiers before they left her to die. She began her song as she was pushed down into the dirt and did not stop singing, no matter what they did to her. She sang of the dusky mountains who watched them that day from the clouds. She sang of the love of a boy and a girl. She sang of flowers and the aroma of the moon as it linked the night with dawn. She did not stop singing. She is still singing. Can you hear her?

Humanity to Harjo is summarized in breathing and naming which lend themselves to continuity and regeneration. Harjo creates a continuum of the saga of human survival baptized in love and nurture on the one hand and grace on the other as paradigms for the transformation of grief and loss into growth and continuity. As Jenny Goodman suggests, grace represents a power of transformation from hate to love (1996:48). Grace begins with the possibility of living with grief. Yet as a shaping poetics, grace is not the transcendence or erasure of pain, but, rather, what enables a culture to survive over time. Eliza Rodriguez Gibson argues that grace emerges in Harjo's work as an organizing principle between memory, myth, and place. It is also an act of negotiating conflicted histories (2002:111) with the aim of seeking a resolution and courage to live with loss. In Mad Love and War, the poem Grace, names grace as an act of seeing, an enlightenment that is larger than the destruction of the enemy and the pain that he may cause. Grace is larger than the memory of a dispossessed people.

I would like to say, with grace, we picked ourselves up and walked into the spring thaw. We didn't; the next season was worse. You went home to Leech Lake to work with the tribe and I went south. And, Wind, I am still crazy.l know there is something larger than the memory o[ a dispossessed people. We have seen it (1)

The poem I Give you Back stands for an exorcism of an enemy that emerges from the inside in Returning from the Enemy. It may also be read as an 
attempt to release not only fear but the atrocities committed in the name of fear, the killings, the rape and the slow starvation. Harjo speaks of the necessity of making "fear an ally instead of just an enemy. I am trying to understand this destructive force and in some way, to take it into myself. Otherwise, it's always going to be the enemy- if it's out there, it will always be your enemy and it will always be following you around" (Moyers 45).

I release you, my beautiful and terrible fear. I release you. You were my beloved and hated twin, but now, I don't know you as myself. I release you with all the pain I would know at the death of my children. You are not my blood any more.

I give you back to the white soldiers who burned down my home, beheaded my children, raped and sodomized my brothers and sisters. I give you back to those who stole the food from our plates when we were starving.

The poem emphasizes vigilance and an adamant refusal to fall for vengeance and the settling of a score. The poem as Elizabeth Archuleta argues offers a strategy for resistance" (109) that I think is based on self love and survival. The naming of forces of evil marks the lines of verse as the appropriated language of the enemy empowers Harjo's release from the grip of annihilation. Self revision as Archuleta elaborates is part of a strategy toward reclaiming oneself (109).

I release you, fear, because you hold these scenes in front of me and I was born with eyes that can never close.

I release you

I release you

I release you

I release you

I am not afraid to be angry.

I am not afraid to rejoice.

I am not afraid to be black.

I am not afraid to be white.

I am not afraid to be hungry.

I am not afraid to be full.

I am not afraid to be hated.

I am not afraid to be loved, to be loved, to beloved, fear.

Repetition is a trade mark of Harjo's work that helps poems "lift off the page and enter into the listener much like a song or a chant" (Harjo, Spiral 17). Repetition has always been used, ceremonially, in telling stories, in effective speaking, so that what is communicated becomes a litany, and gives the reader a way to enter into it, and emerge whole, but changed. Acknowledgement in sharing in acts of evil empowers the will of the speaker and listener to take 
charge and exorcise fear forever. Fear has no place to live in a heart that is determined to do only good.

Oh, you have choked me, but I gave you the leash.

You have gutted me but I gave you the knife.

You have devoured me, but I laid myself across the fire.

I take myself back, fear.

You are not my shadow any longer.

I won't take you in my hands.

You can't live in my eye, my ears, my voice my belly, or in my heart my heart

my heart my heart

But come here, fear

I am alive and you are so afraid of dying.

In the lines above, Harjo claims responsibility in the undoing of her own self in an act of submission as she enumerates the ways in which the enemy has sought her undoing. The powers that Harjo wields in this poem come from her acknowledgement that she too has allowed for the massacre to happen. The decision to claim one's independence from the enemy seeps the power from such an entity and dwarfs it into a phantasm, a shadow that is no longer a reality capable of creating change. The poem calls for an end to the parasitic presence of fear in her body as she expels it. She takes power back, proclaims her life and passes the death sentence on fear that has no hope of survival.

Harjo introduces a new literary tradition that combines the oral and the written as she manages to recreate beauty and existence of landscape and of humans in the wake of destruction. She offers myriad versions of representing the enemy as self, as other, as a concomitant feeling of vengeance and fear that poison one's life with the same venom of the enemy. Victor and vanquished suddenly change places and they become one. War and its concomitant attendants are not only destruction and desecration of innocence but also grace that grows out of pain and helps one become a better human. This is a contradiction that delineates Harjo's philosophy of being. Harjo lifts up her words in prayer as she orchestrates a piece in which music as sound, poetry as word, and myth as narrative impregnate grace. The act of cleansing represented in release from fear is Harjo's act of victory over the dwarfish sentiments of wanting to return an eye for an eye.

\section{Works Cited}

Archuleta, Elizabeth (2006). "I Give you Back: Indigenous Women Writing to Survive." In Sail 88 (4): 88-114.

Bryson, J. Scott (2002). Finding the way Back: Place and Space in the Ecological Poetry of Joy Harjo. In Melus 27 (3 Native American Literature): 169-196.

Coltelli, Laura (1996). Joy Harjo: The Spiral of Memory: Interviews. Ann Arbor: The University of Michigan Press. 
--- (2011) "Forward." In Soul Talk, Song Language: Conversations with Joy Harjo. Wesleyan University Press. Kindle Edition.

Cronyn, George (2012). Native American Poetry. Dove Publications

Fowler, Cynthia, et.al. (2007). "Oklahoma: A View of the Center." In Sail 19 (3): 1-45

Gibson, Eliza Rodriguez (2002). "Love, Hunger, and Grace: Loss and Belonging in the Poetry of Lorna Dee Cervantes and Joy Harjo. In Legacy 19 (1) 106-114.

Goodman, Jenny (1994)."Politics and the Personal Lyric in the Poetry of Joy Harjo and C.D. Wright." In Melus 19 (2 Theory, Culture and Criticism): 35-56.

Gould, Janice (1995). "American Indian Women's Poetry: Strategies of Rage and Hope.” In Signs 20 (4 Postcolonial, Emergent, and Indigenous Feminisms): 797817.

Harjo, Joy (2000). A Map to the Next World: Poetry and Tales. New York: W.W Norton\& Company.

---(2012). Crazy Brave: A Memoir. New York: W.W. Norton\& Company.

---(1983). She Had Some Horses. New York: Thunder House Press.

---(1990). In Mad Love and War. Connecticut: Wesleyan University Press.

---(1994). The Woman Who Fell from the Sky: Poems. New York: W.W. Norton\& Company.

--- \& Stephen Strom (1989). Secrets From the Center of the World. Tucson: Sun Tracks and the University of Arizona Press.

Harjo, Joy, ed. et.al. (1997) Reinventing the Enemy's Language: Contemporary Native Women's Writing of North America. New York: Norton and Company.

Harjo, Joy (2011). Soul Talk, Song Language: Conversations with Joy Harjo. Wesleyan University Press. Kindle Edition.

---. "Music, Poetry, and Stories Returning to the Root Source: Interview with Rebecca Seiferie 2008." In Soul Talk, Song Language: Conversations with Joy Harjo (Kindle Locations 641-644). Wesleyan University Press: Kindle Edition.

---. "Becoming the Thing Itself: Interview with Triplopia 2005." In Soul Talk, Song Language" Conversations with Joy Harjo (Kindle Locations 222-223). Wesleyan University Press: Kindle Edition.

---. "In the Horizon of Light with Joy Harjo: Interview with Ruben Quesada, August 2008." In Soul Talk, Song Language: Conversations with Joy Harjo (Kindle Locations 966-968). Wesleyan University Press. Kindle Edition.

---. "Transcending Writing on Singing Wings: Interview with Tanaya Winder, May 2010. In Soul Talk, Song Language: Conversations with Joy Harjo (Kindle Locations 1128-1129). Wesleyan University Press. Kindle Edition.

---. "You Might as Well Dance: Interview with Harbour Winn, Elaine Smokewood, and John McBryde summer 2009." In Soul Talk, Song Language: Conversations with Joy Harjo (Kindle Locations 1128-1129). Wesleyan University Press. Kindle Edition.

Hernandez Avila, Ines (2002). "It is What Keeps us Sisters"1: Indigenous Women and the Power of Story." In Frontiers 23(2): ix- xviii.

Jaskoski, Helen (1990). "Interview: Joy Harjo.” In Melus 16 (1) Folklore and Orature: 5-13.

Jossa, Emanuela (2007). "The Colors of the Earth: Nature and Landscape in the Poetry of Joy Harjo and Humberto Ak'Abal." In Journal of the Southwest 49 (4):585602.

Kallet, Marilyn (1992). "In Love and War and Music: An interview with Joy Harjo." In The Kenyon Review57-66??.

Lang, Nancy (1993). "Twin Gods Bending Over: Joy Harjo and Poetic Memory." In Melus 18 (3 Poetry and Poetics): 41-9. 
Leen, Mary and Joy Harjo (1995). “An Art of Saying: Joy Harjo's Poetry and the Survival of storytelling. American Indian Quarterly 19 (1): 1-16.

Nixon, Angelique (2006). "Poem and Tale as Double Helix in Joy Harjo's A Map to the Next World." In Sail 18 (1)2-16. ??

Pettit, Ronda (1998). Joy Harjo. Idaho: Boise State University.

Rader, Dean (2002). "Word as Weapon: Visual Culture and Contemporary American Indian Poetry." In Melus 27 (3 Native American Literature): 147-167.

Randall, Margaret (1990). "Nothing to Lose." In The Women's Review of Books: Women Changing in a Changing World 7(10/11):17-18.

Root, Wiluaw Pitt. “About Joy Harjo: A Profile.” In Ploughshares. 180. ??

Ruppert, Jim (1983). "Paula Gunn Allen and Joy Harjo: Closing the Distance between Personal and Mythic Space." American Indian Quarterly 7(1): 27-40.

Ullman, Leslie. "Solitaries and Storytellers: Magicians and Pagans: Five Poems in the World." In The Kenyon Review. 180-193. ???

Wiget, Andrew (1984). The Emergence of Contemporary Native American Poetry. In College English 46(6): 598-609. 
